\title{
Physical exercise and osteoporosis: effects of different types of exercises on bone and physical function of postmenopausal women
}

\author{
Exercício físico e osteoporose: efeitos de diferentes tipos de exercícios \\ sobre o osso e a função física de mulheres pós-menopausadas
}

${ }^{1}$ Division of Endocrinology, School of Medicine, Federal University of São Paulo (Unifesp), São Paulo, SP, Brazil

Linda Denise Fernandes Moreira', Mônica Longo de Oliveira', Ana Paula Lirani-Galvão', Rosângela Villa Marin-Mio', Rodrigo Nolasco dos Santos', Marise Lazaretti-Castro'

\begin{abstract}
Physical exercise is an important stimulus for osteoporosis prevention and treatment. However, it is not clear yet which modality would be better to stimulate bone metabolism and enhance physical function of postmenopausal women. This review paper aims to summarize and update present knowledge on the effects of different kinds of aquatic and ground physical exercises on bone metabolism and physical function of postmenopausal women. Moderate to intense exercises, performed in a high speed during short intervals of time, in water or on the ground, can be part of a program to prevent and treat postmenopausal osteoporosis. Mechanical vibration has proven to be beneficial for bone microarchitecture, improving bone density and bone strength, as well as increasing physical function. Although impact exercises are recognized as beneficial for the stimulation of bone tissue, other variables such as muscle strength, type of muscle contraction, duration and intensity of exercises are also determinants to induce changes in bone metabolism of postmenopausal women. Not only osteoanabolic exercises should be recommended; activities aimed to develop muscle strength and body balance and improve the proprioception should be encouraged to prevent falls and fractures. Arq Bras Endocrinol Metab. 2014;58(5):514-22
\end{abstract}

Keywords

Osteoporosis; bone health; postmenopausal; physical function; physical activity

\section{RESUMO}

Correspondence to:

Linda Denise Fernandes Moreira Ambulatório de Endocrinologia, Universidade Federal de São Paulo Rua Borges Lagoa, 800 04038-030 - São Paulo, SP, Brazil lindafmoreira@gmail.com

Received on Mar/24/2014 Accepted on May/28/2014

DOI: $10.1590 / 0004-2730000003374$
O exercício físico é um estímulo muito importante para o tratamento da osteoporose. Contudo, ainda não está claro qual modalidade seria melhor para estimular o metabolismo ósseo e meIhorar a função física de mulheres pós-menopausadas. Este trabalho visa resumir e atualizar os principais achados sobre os efeitos de diferentes tipos de exercícios aquáticos e de solo para a função física e metabolismo ósseo de mulheres pós-menopausadas. Exercícios moderados a intensos, executados em alta velocidade durante intervalos de tempo curtos, na água ou em solo, podem fazer parte de um programa para prevenir e tratar a osteoporose na pós-menopausa. A vibração mecânica se mostrou benéfica para a microarquitetura óssea, aumentando a densidade e a resistência ósseas, bem como melhorando a função física. Apesar de os exercícios de impacto serem adequados para a estimulação do tecido ósseo, outras variáveis, como força muscular, tipo de contração, duração e intensidade dos exercícios, também são determinantes para induzir mudanças no metabolismo ósseo de mulheres pós-menopausadas. Além da ação sobre o osso, outras atividades que visem aumentar a força muscular e melhorar a propriocepção e o equilíbrio corporal também devem ser encorajadas para a prevenção de quedas e fraturas. Arq Bras Endocrinol Metab. 2014;58(5):514-22

\section{Descritores}

Osteoporose; saúde óssea; pós-menopausa; função física; atividade física 


\section{INTRODUCTION}

$\mathrm{O}$ steoporosis is an osteometabolic disease characterized by substantial loss of bone mass and microarchitecture deterioration of bone tissue, affecting bone quality and strength and increasing fracture risk. Fractures affect the muscle and the skeletal systems, cause chronic pain, loss of functional capacity and compromise quality of life (1).

Osteoporosis is a global health issue, since there are around 200 million people with this disease in the World. Only in the United States, its prevalence will reach 14 million people in 2014 (2). Pharmacological strategies as the use of antiresorptive and anabolic agents that may increase bone mineral density (BMD) and reduce the risk of osteoporotic fractures can be rather expensive. However, general measures of prevention and treatment such as calcium and vitamin D supplementation, the guidance for fall prevention and the practice of specific physical exercises, can be instituted before the manifestation of the disease and may promote other health benefits (3).

Bone tissue is continuously remodeled, and as a dynamic tissue, it adapts and responds to various stimuli, such as physical exercise and mechanical vibration (3). During physical activity mechanical forces can be exerted on bones through ground reaction forces and by the contractile activity of muscles, resulting in maintenance or gain of bone mass. Studies have already pointed out many of the mechanical stimuli that are beneficial to bone tissue, including some physical activities as aquatic and ground exercises $(4,5)$. However, it is not yet fully clarified which would be the best environment, activity type, intensity, frequency or duration of physical exercise to contribute with bone health of postmenopausal women. Moreover, the objectives of this article are to present the most important and latest findings on literature about physical activity in the prevention and treatment of postmenopausal osteoporosis.

\section{MATERIALS AND METHODS}

A literature search was conducted up to February 2014. We considered a total of sixty scientific references focusing on physical exercises and postmenopausal osteoporosis, including books's chapters, original and review articles. Research was carried out at pubmed. org, scielo.com and sciencedirect.com. Keywords used in the research were: menopause, postmenopausal, physical activity, physical exercise, osteoporosis, osteopenia, muscle strength, aerobic training, resistance training, balance training, falls, aquatic exercises, water exercises. The most important findings are summarized in table 1.

\section{IMPACT AND AEROBIC EXERCISES}

Nikander and cols. (6) observed that athletes who participate in aerobic non-weight bearing sports, as cyclists and swimmers, usually present lower BMD compared to the ones taking part in impact sports. The aerobic non-weight bearing sports generate high levels of muscle forces but with no impact forces, and this may be a sign that gravitational loading (impact) is really relevant to bone stimulation (6).

A seven-year longitudinal study (7) followed the changes in bone mass of competitive male master cyclists and found out that many of them had low BMD and a high fracture risk. The authors, thus, recommended alternative exercises (weight lifting, plyometrics, or other high impact activity) as a complement to cycle training to help minimize bone loss in this population. Thinking of postmenopausal women, cycling could be recommended for the improvement of general health, along with another impact weight bearing and strengthening physical activity.

A review on the osteogenic effects of walking, the most commom exercise worldwide, showed that the impact promoted by this activity could improve femoral BMD in postmenopausal women, with no positive effects on spine BMD (8). Another study (9) confirmed that walking as a singular exercise therapy has no significant effects on BMD at the lumbar spine, at the radius, or for the whole body in perimenopausal and postmenopausal women, although significant and positive effects on femoral neck BMD are evident with interventions with more than 6 months in duration. It seems that only the impact of a brisk walking is not enough to stimulate spine BMD in ambulatory postmenopausal women.

Another study (10) compared 44 eldery runners to sedentary controls (over 65 years of age) and found out the runners presented a significantly better total body BMD. Other authors (11) found similar results when comparing sedentary to active postmenopausal women (treadmill walking-30 min + step climbing- $10 \mathrm{~min}$ ): improvement by $2.0 \%(\mathrm{p}>0.05)$ and $6.8 \%(\mathrm{p}<0.05)$ in lumbar and femoral neck, respectively in the training 
Table 1. A summary of the most important findings on different modalities of physical exercise and bone health

\begin{tabular}{|c|c|c|}
\hline $\begin{array}{l}\text { Exercise } \\
\text { modalities }\end{array}$ & Ref. & Findings \\
\hline \multirow{6}{*}{$\begin{array}{l}\text { Impact and } \\
\text { aerobic } \\
\text { exercises }\end{array}$} & (6) & Aerobic non-weight bearing sports (cycling and swimming) usually lead to a lower BMD compared to impact sports \\
\hline & (7) & $\begin{array}{l}\text { Competitive male master cyclists had low BMD and a high risk for fractures. The authors recommended alternative exercises (weight } \\
\text { lifting, plyometrics or other high impact activity) as a complement to cycle training to help minimize bone loss }\end{array}$ \\
\hline & (8) & The impact promoted by walking could improve femoral BMD in postmenopausal women, with no positive effects on spine BMD \\
\hline & (9) & $\begin{array}{l}\text { Walking as a singular exercise therapy has no significant effects on BMD at the lumbar spine, at the radius, or for the whole body in } \\
\text { perimenopausal and postmenopausal women, although there were significant and positive effects on femoral neck BMD }\end{array}$ \\
\hline & (10) & $\begin{array}{l}\text { Compared } 44 \text { eldery runners to sedentary controls (over } 65 \text { years of age) and found out the runners presented a significantly better total } \\
\text { body BMD }\end{array}$ \\
\hline & (12) & $\begin{array}{l}\text { After } 6 \text { months of strengthening, high-impact or no exercise (control) there was a significant increase in the BMD at the spine and femoral } \\
\text { neck in the high-impact group compared to the strengthening and control groups }\end{array}$ \\
\hline \multirow{7}{*}{$\begin{array}{l}\text { Resistance } \\
\text { exercises }\end{array}$} & (13) & $\begin{array}{l}\text { Physical activities involving impact forces (generating both gravitation and muscle loading), tended to have a slightly better effect on bone } \\
\text { metabolism and reduction of fracture risk than isolate no-impact resistance training, as weight lifting }\end{array}$ \\
\hline & (14) & $\begin{array}{l}\text { The type of exercise that better benefit BMD of femoral neck was no-impact high intensity resistance training for lower limb. The authors } \\
\text { also concluded that for the BMD of spine combined exercises (resistance + aerobic + impact) seem to be most recommended }\end{array}$ \\
\hline & (18) & $\begin{array}{l}\text { A program of moderate to high intensity ( } 70 \text { to } 90 \% \text { of one maximum repetition-1RM) resistance training, with } 3 \text { to } 4 \text { bouts of } 8 \text { to } 12 \\
\text { repetitions of each exercise, performed } 2 \text { or } 3 \text { times a week, can maintain or improve the BMD of hip and femur in postmenopausal } \\
\text { women }\end{array}$ \\
\hline & (19) & $\begin{array}{l}\text { Interventions on older adults with osteoporosis or osteopenia revealed that resistance training have a beneficial effect on the domains of } \\
\text { physical function and activities of daily life }\end{array}$ \\
\hline & (20) & $\begin{array}{l}\text { Resistance exercises performed } 4 \text { times a week, in a very dynamic way (resistance }+ \text { velocity }=\text { Power training) with high loads }(70 \% \text { to } \\
90 \% \text { of } 1 \text { RM) and few repetitions ( } 6 \text { repetitions) are recommended }\end{array}$ \\
\hline & (22) & $\begin{array}{l}\text { Strengthening the back extensor muscles in postmenopausal women can lead to a significant reduction in vertebral fracture, as well as } \\
\text { the enhancement of body balance and fall reduction }\end{array}$ \\
\hline & (23) & $\begin{array}{l}\text { Increasing the strength of back extensor muscles reduced the incidence of new vertebral fractures in patients that underwent } \\
\text { vertebroplasty surgery }\end{array}$ \\
\hline \multirow{5}{*}{$\begin{array}{l}\text { Balance and } \\
\text { proprioception } \\
\text { exercises }\end{array}$} & $(27,28)$ & Gait re-education, exercises and techniques designed to improve posture should be proposed to postmenopausal women \\
\hline & $(29)$ & $\begin{array}{l}\text { Gait re-education and proprioceptive exercises should also be performed in a swimming pool (water at the xiphoid process level) because } \\
\text { water can add an "extra" imbalance to these exercises }\end{array}$ \\
\hline & (31) & $\begin{array}{l}18 \text { weeks of resistance, proprioception and balance training can reduce the number of falls, improve functional capacity, dynamic balance } \\
\text { and quality of life when compared to the control group. The incidence of falls was reduced by } 38 \% \text { in the training group, versus a } 16 \% \\
\text { reduction in the control group }\end{array}$ \\
\hline & (32) & $\begin{array}{l}\text { Tai-chi Chuan ( } 3 \text { times a week, during } 12 \text { weeks) in } 77 \text { postmenopausal women, improved by } 17.8 \% \text { the knee extensor strength and } \\
26.1 \% \text { the static balance, without changes in control group }\end{array}$ \\
\hline & (33) & $\begin{array}{l}\text { The risk of falls in osteopenic post-menopausal women was evaluated before and after } 24 \text { weeks of tai chi training. There was an } \\
\text { improvement in tread width, stability of the trunk and a decrease in the number of falls }\end{array}$ \\
\hline \multirow{5}{*}{$\begin{array}{l}\text { Whole body } \\
\text { vibration }\end{array}$} & $(36,37)$ & $\begin{array}{l}\text { Experimental work showed that the mechanical vibration may be beneficial for bone microarchitecture, improving bone density and bone } \\
\text { strength }\end{array}$ \\
\hline & (38) & $\begin{array}{l}\text { Vibratory stimuli in the form of a vibrating platform of low frequency and intensity }(30 \mathrm{~Hz}, 0.2 \mathrm{~g}) \text { inhibited bone loss in the spine and femur } \\
\text { in osteopenic women with low weight after one year of treatment }\end{array}$ \\
\hline & (39) & The mechanical vibration mitigates bone loss mainly in the femoral site \\
\hline & (41) & $\begin{array}{l}\text { After } 8 \text { weeks of mechanical vibration ( } 30 \mathrm{~Hz}, 0.3 \mathrm{~g}, 20 \mathrm{~min} \text { ) in postmenopausal women the NTx/Cr (urine resorption marker) was } \\
\text { significantly reduced by } 34.6 \% \text { compared to control group }\end{array}$ \\
\hline & (42) & $\begin{array}{l}\text { The isolated effect of low frequency vibration versus walking ( } 3 \text { x/week, for } 8 \text { weeks) in post-menopausal women was studied and the } \\
\text { vibration group showed better results than control group, improving the femoral neck BMD by } 4.3 \% \text { and the body balance by } 29 \%\end{array}$ \\
\hline \multirow{4}{*}{$\begin{array}{l}\text { Aquatic } \\
\text { exercises }\end{array}$} & $(49,50)$ & $\begin{array}{l}\text { High impact sports seem to be more osteogenic than no-impact sports such as swimming or cycling, in children, young adults or older } \\
\text { adults }\end{array}$ \\
\hline & (51) & $\begin{array}{l}\text { Swimming does not seem to negatively affect bone mass: swimmers and sedentary controls have similar BMD values. However, } \\
\text { swimmers presented a higher bone turnover than sedentary controls that may result in a stronger structure and consequently in a } \\
\text { stronger bone }\end{array}$ \\
\hline & (5) & $\begin{array}{l}\text { A 24-week high intensity aquatic exercise program (HydrOS) decreased number of fallers and strongly improved neuromuscular } \\
\text { parameters }\end{array}$ \\
\hline & (54) & $\begin{array}{l}\text { A 24-week high-intensity aquatic exercise program (HydrOS), increased bone formation marker (P1NP) and decreased the increment rate } \\
\text { of bone resorption marker (CTx) and prevented the bone loss at femoral trochanter }\end{array}$ \\
\hline
\end{tabular}


group, whereas the control group lost $2.3 \%(\mathrm{p}<0.05)$ and $1.5 \%(\mathrm{p}>0.05)$ in the BMD of the same sites.

Basat and cols. (12), studied 42 postmenopausal women allocated to three groups receiving strengthening exercise, high-impact exercise or no exercise (control). After 6 months there was a significant increase in the BMD at the lumbar spine $(\mathrm{p}=0.017)$ and femoral neck $(\mathrm{p}=0.013)$ in the high-impact group compared to the strengthening and control groups. Serum osteocalcin (OC), a bone formation marker, increased ( $\mathrm{p}=$ 0.033 ) and NTx, a bone resorption marker, decreased significantly ( $\mathrm{p}=0.034)$ only in the high-impact group. These results show that impact forces are a relevant element in the stimulation of bone metabolism.

\section{RESISTANCE EXERCISES}

It seems that the two major ways to stimulate bone metabolism through exercises are by using resistance and impact exercises. In 2009, Wendy and cols. (13), declared that, although the lack of conclusive evidence, it seemed that physical activities involving impact forces, and therefore generated both gravitation and muscle loading, tended to have a slightly better effect on bone metabolism and reduction of fracture risk than isolate no-impact resistance training, as weight lifting. However, as elderly people usually present other joint limitations, such as osteoarthritis, herniated discs, vertebral fractures and knee problems, impact exercises are not always feasible to this population. In these cases no-impact resistance training is recommendable.

Contrarily, Howe and cols. (14) analyzed many randomized control trials (RCTs) including 4,320 participants, and verified that the type of exercise that better benefit femoral neck BMD was the lower limb no-impact high intensity resistance training. The authors also concluded that for the spine BMD combined exercises (resistance + aerobic + impact) seem to be most recommended.

During resistance training the variety of muscles forces applied to bone (at places where tendons are attached) generate stimuli capable of promoting a bone osteogenic response (15). This mechanism promotes actions like tension, compression and torsion, creating electrical signals able to stimulate the bone metabolism and the mineral apposition at the places that suffered the muscle-tendon forces (16), increasing the BMD and possibly inhibiting bone resorption (17). A resistance training program of moderate to high intensity
(70 to $90 \%$ of one maximum repetition-1RM), including 3 to 4 bouts of 8 to 12 repetitions of each exercise, performed 2 or 3 times a week, is able to maintain or improve the BMD of hip and femur in postmenopausal women when performed over one year duration (18).

Despite the effects of resistance training on bone mass and metabolism, a systematic review on the effects of resistance exercises on function in older adults with osteoporosis or osteopenia, revealed that interventions using resistance training have a beneficial effect on the domains of physical function and activities of daily life (19).

Studies have shown that exercises that stimulate bone formation usually present the following characteristics: dynamism, high intensity and short duration of stimulus $(4,5)$. Resistance exercises performed 4 times a week, in a very dynamic way (resistance + velocity $=$ Power training) with high loads (70\% to $90 \%$ of $1 \mathrm{RM})$ and few repetitions (6 repetitions) are recommended, once this kind of strategy involves vigorous muscle contractions and demand the action of fiber type II (most capable of stimulating bone formation) (20).

In this context, Stengel and cols. conducted a randomized trial (21) in which 53 pre-trained women (mean age 58.2 years) were randomized into a strength training (ST) or power training (PT) group. The difference between the groups was the movement velocity during the resistance training: ST - 4 seconds for concentric and 4 seconds for eccentric contraction; PT - explosive concentric and 4 seconds for eccentric contraction). After 2 years of training, women submitted to PT maintained lumbar spine BMD, while ST lost $2.4 \%$. The authors concluded that power training might be superior to strength training to maintain BMD in postmenopausal women. In addition, power training was safe, as it did not lead to increased injury or pain.

The strengthening of the back extensor muscles has been the focus of many studies so far. Sinaki and cols. (22) observed that by improving the back extensors muscle force in postmenopausal women a significant reduction in vertebral fracture occurred, as well as the enhancement of body balance and fall reduction. In the same line, other study showed that the increase in the back extensors strength reduced the incidence of new vertebral fractures in patients that underwent vertebroplasty surgery (23). This way, the strengthening of back extensor muscles should be a target in a physical training program for postmenopausal women. 


\section{BALANCE AND PROPRIOCEPTIVE EXERCISES}

When vertebral fractures occur, the vertebral bodies collapse and this may result in increased hyperkyphosis, which may provoke anteroposterior oscillation of the trunk and, consequently, balance loss (24). In addition, the proprioceptors located in the paravertebral muscles will also present reduced sensitivity to the perception of straightening of the trunk, contributing to the increase of fall risk (25).

Along with the gait re-education, exercises and techniques designed to improve posture are very important to this population $(26,27)$. Initially, gait must be trained by working with the muscle groups involved in it, such as the hip flexors (which help to get the heel off the floor), knee extensors and hallux extensors as well, because when touching the ground they trigger the gluteus maximum muscles, important in the discharge of the trunk in front (26). Some examples of exercises to improve gait and balance would be (preferably barefoot): walk with enlarged base of sustentation, walk in different directions, walk on the heels and on the toes, small jumps (for people who do not have an increased fracture risk), weight transfer from one leg to another, unipedal support and coordination exercises of upper and lower limbs (28). It is also beneficial to perform this type of training in a swimming pool (water at the xiphoid process level) because water can add an "extra" imbalance to these exercises when one is immersed and also provide additional resistance, collaborating to muscle strengthening (29).

Proprioception is the term used to describe the awareness of position or postural movement, in the perception of gravity and/or the position of the parts of the body. The proprioceptors are present in the joints, tendons, ligaments and they send information regarding the spatial organization of the segments to the central nervous system (CNS) (30). Proprioception training is important because in addition to the visual and vestibular systems, it helps to improve postural control. Thus, the association between muscle strengthening and proprioceptive exercises is essential to improve mobility. A study performed by Teixeira and cols. (31) demonstrated in 100 women over 55 years that 18 weeks of resistance, proprioception and balance training can reduce the number of falls, improve functional capacity, dynamic balance and quality of life when compared to the control group. The incidence of falls was reduced by $38 \%$ in the training group, versus a $16 \%$ reduction in the control group.
Exercises that encourage the proprioception and dynamic stabilization, such as destabilization in balance boards and trampoline, can also be used depending on the physical condition of the patients (29). Pereira and cols. (32) investigated the effects of Tai-chi Chuan (three times a week, during 12 weeks) in 77 postmenopausal women. The training improved by $17.8 \%$ the knee extensor strength and $26.1 \%$ the static balance, without changes in control group. Chyu and cols. (33) evaluated the risk of falls in osteopenic post-menopausal women before and after 24 weeks of tai chi training and concluded that this practice improved tread width (important for the gait improvement), trunk stability and, therefore, decrease the number of falls. In addition to Tai-chi, dancing, especially ballroom dancing, can also be recommended because it helps training weight transfer, coordination and proprioception.

\section{WHOLE BODY VIBRATION}

In addition to the specific exercises, physical resources such as vibratory stimuli are also being employed for the improvement and maintenance of musculoskeletal conditions in people with low bone mass. Various in vitro studies with different frequencies and intensities have been conducted to stimulate osteoblasts, osteocytes and osteoclasts $(34,35)$ as well as experimental work showing that the mechanical vibration may be beneficial for bone microarchitecture, improving bone density and strength $(36,37)$.

Rubin and cols. (38) demonstrated that vibratory stimuli in the form of a vibrating platform of low frequency and intensity $(30 \mathrm{~Hz}, 0.2 \mathrm{~g})$ inhibited bone loss in the spine and femur in osteopenic women with low weight $(\mathrm{n}=70)$ after one year of treatment. The placebo group lost $2.13 \%$ of femoral neck BMD and $1.6 \%$ of spine BMD, whereas the platform group prevented the bone loss. Further, many other studies were conducted with different protocols to observe the mechanical vibration effects on bone mass, bone markers and muscle strength $(39,40)$. A former meta-analysis concluded that the mechanical vibration mitigates bone loss mainly in the femoral site (39). Bone remodeling markers also suffer influence of mechanical vibration, and some studies have shown a reduction of the values of NTX and CTX, markers of bone resorption. Turner and cols. (41) studied the dose-response relation with mechanical vibration $(30 \mathrm{~Hz}, 0.3 \mathrm{~g}, 20 \mathrm{~min})$ in postmenopausal women and noted that after 8 weeks NTx/Cr (urine 
resorption marker) was significantly reduced by $34.6 \%$ compared to control group.

Few researchers have studied the effects of isolated vibration. Gusi and cols. (42) studied the isolated effect of low frequency vibration versus walking $(3 \mathrm{x} /$ week, for 8 weeks) in post-menopausal women and found that the vibration group showed better results than controls, improving femoral neck BMD by $4.3 \%$ and body balance by $29 \%$.

Although evidences suggest the use of the vibrating platforms in the prevention and treatment of osteoporosis, it is important to emphasize that low intensities and low amplitudes (cited in the studies above) are more suitable for individuals with a higher risk of fractures (43), being a safer strategy to this population. While more studies are necessary to understand more deeply the effects of mechanical vibration on bone metabolism, low intensity mechanical vibration has been shown to improve musculoskeletal parameters and can be a useful tool as part of the prevention and treatment protocol for osteoporosis.

\section{AQUATIC EXERCISES}

Many of the studies that found positive effects of exercises on bone mass and metabolism included jumps and high impact physical activities $(44,45)$ that not always can be practiced by elderly. Apart from bone fragility, this population frequently presents other musculoskeletal impairment (46), which prevent them from being involved in high impact physical activities. In these cases, none or low impact exercises should be recommen$\mathrm{ded}$, as resistance training or aquatic exercises.

It is known that bone tissue responds to mechanical load applied either through muscle contraction or impact (gravitational) forces; for so, loads have to exceed the ones applied to bone during everyday life (47). Studies with no-impact exercises (weight lifting) showed positive effects on bone mass, due to the action of muscle tension stimulating bone tissue $(14,21)$. Thus, the muscle-tendon-bone interaction during the resistance exercise, even with no impact, could develop some osteogenic effect on bone.

Aquatic exercises such as swimming or vertical water exercise in which the participant stays standing (with water-high at the xiphoid appendices level) apply no or a low impact on bone, once in water the fluctuation is in charge of maintaining the persons' body fluctuating (48). The reduction of the gravity forces on human body when immersed in water makes aquatic exercise more comfortable and tolerable to elderly people with joint diseases. Some literature reviews have shown that high impact sports seem to be more osteogenic than no-impact sports such as swimming or cycling, in children (49), young adults (49) or older adults (50). These arguments lead many health professionals to avoid recommending aquatic exercises for the prevention and treatment of osteoporosis.

Nevertheless, Gómez-Bruton and cols. (51), in a review study focusing on swimmers' bone mass, metabolism and structure, observed that swimming does not seem to negatively affect bone mass, as many believe, although it may not be one of the best sports to be practiced in order to increase this parameter, due to the hypogravity and lack of impact. This review paper showed that swimmers and sedentary controls have similar BMD values. However, swimmers presented a higher bone turnover than sedentary controls that may result in a stronger structure and consequently in a stronger bone, concluded the authors.

The guideline on physical activity and bone health published by the American College of Sports Medicine (52) recommends that exercise programs for elderly people should include weight-bearing endurance and resistance activities aimed at preserving bone mass, and also activities designed to improve balance and prevent falls. The aquatic environment in a pool is propitious to the development of body balance and muscle strength (5), once water waves caused by the persons' movements challenges the gravity center making it difficult to stay balanced and stable, this way, stimulating the action of trunk muscles that help to control body balance (53).

There have been reported bone responses after aquatic exercises in the vertical position performed by postmenopausal women, with positive effects on their physical function (53), but a real reduction in fall incidence was not observed among this population. Moreira and cols. (5), however, conducted a high intensity aquatic exercise protocol, called HydrOS, that included 108 postmenopausal women $(58.8 \pm 6.4$ years of age) randomized into Control group $(\mathrm{CG} ; \mathrm{n}=44)$ and Aquatic exercise group (AEG; $\mathrm{n}=64$ ). Both groups received elementary calcium $500 \mathrm{mg} /$ day and cholecalciferol 1,000 IU/day. For 24 weeks, the AEG participated in the aquatic exercise program, whereas the CG remained sedentary. After the program the number of falls and fallers in the CG remained unchanged, whe- 
reas in the AEG, the mean number of falls decreased from 2.00 to 0.29 ( $\mathrm{p}<0.0001$ ), and the number of fallers decreased by $44 \%(\mathrm{p}<0.0001)$. All neuromuscular variables significantly improved in the AEG: flexibility $(26.6 \%$; $<<0.0001)$, unipedal stance $(14.1 \%$; $<$ $0.001)$, mobility $(23.7 \% ; \mathrm{p}<0.001)$, handgrip strength $(13.4 \% ; \mathrm{p}<0.001)$, strength of back extensor muscles $(26.2 \% ; \mathrm{p}<0.001)$, strength of hip flexor muscles $(18.5 \% ; \mathrm{p}=0.039)$, and knee extensor muscles $(7.7 \%$; $\mathrm{p}<0.001)$. In the CG, significant improvements in flexibility $(12.2 \%$; $=0.009)$, unipedal stance $(4.5 \%$; $<0.001)$, mobility $(10 \% ; \mathrm{p}<0.001)$, and strength of hip flexors $(5.7 \% ; \mathrm{p}=0.039)$ were observed and could be explained by increasing serum 25 -hydroxyvitamin D level attributable to supplementation.

In another arm of the previous study, Moreira and cols. (54) evaluated the 24-week effects of a high-intensity aquatic exercise program (HydrOS) on bone remodeling markers and bone mass of postmenopausal women. Results showed an augment in bone formation marker (PINP) only in the AEG (15.8\%; $\mathrm{p}=$ $0.001)$, and although both groups experienced significant enhancements in bone resorption marker $(\mathrm{CTx})$, this increase was less considerable in the AEG ( $15 \%$ in the AEG and $29 \%$ in the CG). The femoral trochanter $\mathrm{BMD}$ presented a $1.2 \%$ reduction in the $\mathrm{CG}(\mathrm{p}=$ $0.009)$, whereas in the AEG no change was observed $(\mathrm{p}=0.069)$, showing that the aquatic exercise program was efficient in attenuating bone resorption raise and enhancing bone formation, which prevented the participants in the AEG from reducing the femoral trochanter BMD, as happened in the CG.

These previous studies showed that apart from hypogravity and the significant reduction in impact during the aquatic exercises in the vertical position, it was possible to stimulate bone metabolism through exercises against the water resistance, executed with the maximum speed, wide range of motion, few repetitions and high intensity. The results also showed that a high intensity aquatic exercise program can significantly improve body balance and reduce falls, one of the major implications of postmenopausal osteoporosis.

\section{PRECAUTION DURING EXERCISES}

When prescribing an exercise program to prevent or treat postmenopausal osteoporosis, some precautions should be taken to guarantee the effectiveness and safety of the program. First recommendations would be to wear very well tied shoes and with adherent so- les; and also start the exercise session with a warm up (organic activity, e.g. walking; joint rotations or gentle stretching). During all the exercise execution the participant should maintain a good body posture, to prevent muscle pain and fracture. During exercises of destabilization in balance boards and trampoline, the patient should stand in front of a wall or a fixed bar on the wall, where he/she can hold in case of a slip, to prevent a fall.

It is very important to strengthen the abdominal muscles, used in the maintanance of good body posture during almost all activities of daily life, and also necessary for the normal spine functioning. And it is notorious that one of the main actions of the abdominal muscles is the spine flexion, however, this kind of movement lead to a lot of stress at the vertebral body, and in case the person presents bone fragility, a fracture may happen. Early in 1966 Nachemson (55) detected that spine flexion was the position that most stressed the vertebral bodies. Later in 1984, Sinaki and Mikkelsen (56) figured out that from a group of osteoporotic postmenopausal women that performed spine flexions as an exercise routine, $89 \%$ presented vertebral fractures after a period of two years. Since than, studies with osteoporotic people performing spine flexion exercises are not carried out anymore. Abdominal exercises can be safely proposed to osteoporotic women with the following strategies: isometric contractions with the spine aligned in the physiologic position without Valsalva maneuver, semi hip flexions with the person lying on the floor, hip anteversion and retroversion, and forced exhaling.

Another precaution would be not to exclusively trust the results of the dual-energy X-ray absorptiometry (DXA) exams. Sometimes DXA exams may show normal values for a person's bone mass, when, in fact, that bone is of poor quality and fragile, because of corticosteroids action (57). Fractures due to the use of oral corticosteroid occur in the presence of higher bone density than is the case for patients with involutional osteoporosis (58). So, consider other factors rather then DXA exams, such as age, genetics, previous fracture, calcium and vitamin D ingestion and use of alcohol, cigarettes and corticosteroids, all elements that can diminish bone quality and increase the risk of fractures (59).

\section{CONCLUSIONS}

Walking as an exercise program can improve the femoral BMD in postmenopausal women, but not the spine 
BMD in this population. A combined exercise program (resistance + aerobic + impact) is recommended for an enhancement of spine BMD. Although impact exercises are recognized as beneficial for bone tissue stimulation, it seems that other variables such as muscle strength, type of muscle contraction, duration and intensity of exercises are also determinants to induce changes in bone metabolism of postmenopausal women. It is important to emphasize that not only osteogenic exercises should be recommended; activities aimed to develop muscle strength and body balance and improve the proprioception should be encouraged to prevent falls and fractures.

Many different exercise modalities as suitable to be practiced by postmenopausal women for the prevention and treatment of osteoporosis, such as weight lifting, walking, running, jumping, step climbing, and even swimming and water aerobics, as long as the programs include moderate to intense exercises (70\% to $90 \%$ of $\mathrm{IRM}$ ), are performed in a high speed during short intervals of time, in a frequency of 2 to 4 times a week. Mechanical vibration has also proven to stimulate bone metabolism and physical function in the postmenopausal period, being a very safe and feasible alternative to this population.

Postmenopausal women should engage in exercises with some precautions, to avoid the risk of injuries and fractures. For so, it is strictly recommended that after consulting with a physician, patient follows an exercise program prescribed by a specialist at the area: a physical education professional or a physiotherapist.

Disclosure: no potential conflict of interest relevant to this article was reported.

\section{REFERENCES}

1. National Osteoporosis Foundation (NOF). Clinician's Guide to Prevention and treatment of Osteoporosis; 2010.

2. Burge R, Dawson-Hughes B, Solomon DH, Wong JB, King A, Tosteson A. Incidence and economic burden of osteoporosis-related fractures in the United States, 2005-2025. J Bone Miner Res. 2007;22:465-75.

3. Kelley GA, Kelley KS, Kohrt WM. Exercise and bone mineral density in premenopausal women: a meta-analysis of randomized controlled trials. Int J Endocrinol. 2013;2013:741639.

4. Vieira S. Different land-based exercise training programs to improve bone health in postmenopausal women. Med Sci Tech. 2013; 54:158-63.

5. Moreira L, Fronza FC, dos Santos RN, Teixeira LR, Kruel LF, Lazaretti-Castro M. High-intensity aquatic exercises (HydrOS) improve physical function and reduce falls among postmenopausal women. Menopause. 2013;20(10):1012-9.
6. Nikander R, Kannus P, Dastidar P, Hannula M, Harrison L, Cervinka T, et al. Targeted exercises against hip fragility. Osteoporos Int. 2009;20(8):1321-8.

7. Nichols JF, Rauh MJ. Longitudinal changes in bone mineral density in male master cyclists and nonathletes. J Strength Cond Res. 2011;25(3):727-34.

8. Martyn-St JM, Carroll S. Meta-analysis of walking for preservation of bone mineral density in postmenopausal women. Bone. 2008;43(3):521-31.

9. Ma D, Wu L, He Z. Effects of walking on the preservation of bone mineral density in perimenopausal and postmenopausal women: a systematic review and meta-analysis. Menopause. 2013;20(11):1216-26.

10. Velez NF, Zhang A, Stone B, Perera S, Miller M, Greenspan SL. The effect of moderate impact exercise on skeletal integrity in master athletes. Osteoporos Int. 2008;19(10):1457-64.

11. Chien MY, WuYT, Hsu AT,Yang RS, Lai JS. Efficacy of a 24-week aerobic exercise program for osteopenic postmenopausal women. CalcifTissue Int. 2000;67(6):443-8.

12. Basat $H$, Esmaeilzadeh $S$, Eskiyurt $N$. The effects of strengthening and high-impact exercises on bone metabolism and quality of life in postmenopausal women: a randomized controlled trial. J Back Musculoskelet Rehabil. 2013;26(4):427-35.

13. Wendy MK, Barry DW, Schwartz RS. Muscle forces or gravity: what predominates mechanical loading on bone? Med Sci Sports Exerc. 2009;41(11):2050-5.

14. Howe TE, Shea B, Dawson LJ, Downie F, Murray A, Ross C, et al. Exercise for preventing and treating osteoporosis in postmenopausal women. Cochrane Database Syst Rev. 2011;6(7):CD000333.

15. Turner $\mathrm{CH}$, Robling AG. Mechanisms by which exercise improves bone strength. J Bone Miner Metab. 2005;23 Suppl:16-22.

16. Menkes A, Mazel S, Redmond RA, Koffler K, Libanati CR, Gundberg $\mathrm{CM}$, et al. Strength training increases regional bone mineral density and bone remodeling in middle-aged and older men. J Appl Physiol (1985). 1993;74(5):2478-84.

17. Iwamoto J. Effects of physical activity on bone: what type of physical activity and how much is optimal for bone health? J Osteopor Phys Act. 2013;1:101.

18. Zehnacker $\mathrm{CH}$, Bemis-Dougherty A. Effect of weighted exercises on bone mineral density in post menopausal women. A systematic review. J Geriatr Phys Ther. 2007;30(2):79-88.

19. Wilhelm M, Roskovensky G, Emery K, Manno C, Valek K, Cook C. Effect of resistance exercises on function in older adults with osteoporosis or osteopenia: a systematic review. Physiother Can. 2012;64(4):386-94.

20. Turner $\mathrm{CH}$. Aging and fragility of bone. J Musculoskelet Neuronal Interact. 2007;7(4):342-3.

21. von Stengel S, Kemmler W, Kalender WA, Engelke K, Lauber D. Differential effects of strength versus power training on bone mineral density in postmenopausal women: a 2-year longitudinal study. Br J Sports Med. 2007;41(10):649-55.

22. Sinaki M, Itoi E, Wahner HW, Wollan P, Gelzcer R, Mullan BP, et al. Stronger back muscles reduce the incidence of vertebral fractures: a prospective 10 year follow-up of postmenopausal women. Bone. 2002;30(6):836-41.

23. Huntoon EA, Schmidt CK, Sinaki M. Significantly fewer refractures after vertebroplasty in patients who engage in back-extensor-strengthening exercises. Mayo Clin Proc. 2008;83(1):54-7.

24. Vasconcelos FM, Trevisan DC, Costa GC, Matos MS, Reis JG, Abreu DCC. Thoracic kyphosis degree and its interference with static balance and dynamic task in elderly women. Geriatria \& Gerontologia. 2010; 4(4):194-202. 
25. Teixeira L. Atividade física adaptada em saúde: da teoria à prática. Pedrosa MAC, Pfrimer LDM, Oliveira ML, Castro ML. In: Atividades físicas adaptadas para osteoporose. Capítulo 8, $1^{\mathrm{a}}$ edição. Phorte Editora, 2008;169-90.

26. Silva ACLG, Mannrich $G$. Pilates on rehabilitation: a systematic review. Fisioter Mov. 2009;22(3):449-55.

27. Castro MP. Thoracic kyphosis treated with global posture reeducation. Arq Ciênc Saúde Unipar. 2000;4(2):159-64.

28. Bilar EM, Pillare AC. Osteoporosis. Etiology, diagnosis and treatment. Physical exercise and rehabilitation in the prevention and treatment of osteoporosis. Lirani-Galvão APR, Moreira-Pfrimer LDM, Marin RV, Oliveira ML, Pedrosa-Castro MAC, Lazaretti-Castro M. In: Chapter 10; $1^{\text {a }}$ Edition, Biomedical. p. 217-34.

29. Moreira LDF, Fronza FC, Dos Santos RN, Teixeira LR, Kruel LF, Castro ML. High-intensity aquatic exercises (HydrOS) improve physical function and reduce falls among postmenopausal women. Menopause. 2013;20(10):1012-9.

30. Burke RE. Sir Charles Sherrington's. The integrative action of the nervous system: a centenary appreciation. Brain. 2007;130(Pt 4):887-94.

31. Teixeira L, Peccin S, Silva K, Teixeira T, Imoto AM, Magalhães $J$, et al. The effectiveness of progressive load training associated to the proprioceptive training in topics in osteoporosis. 2010;46:216-39.

32. Pereira MM, Oliveira RJ, Silva MAF, Souza LHR, Vianna LG. Effects ofTai Chi Chuan on knee extensor muscle strength and balance in elderly women. Rev Bras Fisioter. 2008;12(2):121-6.

33. Chyu MC, James CR, Sawyer SF, Brismée JM, Xu KT, Poklikuha $\mathrm{G}$, et al. Effects of tai chi exercise on posturography, gait, physical function and quality of life in postmenopausal women with osteopenia: a randomized clinical study. Clin Rehabil. 2010;24(12):1080-90.

34. Shikata T, Shiraishi T, Morishita S, Takeuchi R, Saito T. Effects of amplitude and frequency of mechanical vibration stimulation on cultured osteoblasts. System Design and Dynamics J. 2008;2(1):382-8.

35. Lau E, Al-Dujaili S, Guenther A, Liu D, Wang L, You L. Effect of low-magnitude, high-frequency vibration on osteocytes in the regulation of osteoclasts. Bone. 2010;46(6):1508-15.

36. Rubin C, Turner AS, Müller R, Mittra E, McLeod K, Lin W, et al. Quantity and quality of trabecular bone in the femur are enhanced by a strongly anabolic, noninvasive mechanical intervention. J Bone Miner Res. 2002;17(2):349-57.

37. de Oliveira ML, Bergamaschi CT, Silva OL, Nonaka KO, Wang CC, Carvalho AB, et al. Mechanical vibration preserves bone structure in rats treated with glucocorticoids. Bone. 2010;46(6):1516-21.

38. Rubin C, Recker R, Cullen D, Ryaby J, Mccabe J, Mcleod K. Prevention of postmenopausal bone loss by a low-magnitude, high-frequency mechanical stimuli: a clinical trial assessing compliance, efficacy, and safety. J Bone Miner Res. 2004;19(3):343-51.

39. Lau RW, Liao LR, Yu F, Teo T, Chung RC, Pang MY. The effects of whole body vibration therapy on bone mineral density and leg muscle strength in older adults: a systematic review and meta-analysis. Clin Rehabil. 2011;25(11):975-88.

40. Sherk VD, Chrisman C, Smith J, Young KC, Singh H, Bemben MG, et al. Acute bone marker responses to whole-body vibration and resistance exercise in young women. J Clin Densitom. 2013;16(1):104-9.

41. Turner S, Torode M, Climstein M, Naughton G, Greene D, Baker MK, et al. A randomized controlled trial of whole body vibration exposure on markers of bone turnover in postmenopausal women. J Osteoporos. 2011;2011:710387.

42. Gusi N, Raimundo A, Leal A. Low-frequency vibratory exercise reduces the risk of bone fracture more than walking: a randomized controlled trial. BMC Musculoskelet Disord. 2006;7:92.

43. Kiiski J, Heinonen A, Järvinen TL, Kannus P, Sievänen H.Transmission of vertical whole body vibration to the human body. $J$ Bone Mineral Res. 2008;23(8):1318-25.

44. Nordström P, Nordström G, Lorentzon R. Massive increase in bone density by high impact loading exercise in a 26 -year-old ostoeporotic woman on high doses of glucocorticoids. BMC Musculoskelet Disord. 2012;98(2):196.

45. Gianoudis J, Bailey CA, Sanders KM, Nowson CA, Hill K, Ebeling PR, et al. Osteo-cise: Strong Bones for Life': Protocol for a Community-based Randomised Controlled Trial of a Multi-modal Exercise and Osteoporosis Education Program for Older Adults at Risk of Falls and Fractures. BMC Musculoskelet Disord. 2012;13(78):1-16.

46. Floras JS, Notarius CF, Harvey PJ. Exercise training--not a class effect: blood pressure more buoyant after swimming than walking. J Hypertens. 2006;24(2):269-72.

47. Kohrt WM, Barry DW, Schwartz RS. Muscle forces or gravity: what predominates mechanical loading on bone? Med Sci Sports Exerc. 2009;41(11):2050-5.

48. Bates $A$, Hanson N. Exercícios aquáticos terapêuticos. São Paulo: Ed. Manole, 1998.

49. Karlsson MK, Nordqvist A, Karlsson C. Physical activity increases bone mass during growth. Food Nutr Res. 2008;52:10.3402/ fnr.v52i0.1871.

50. Guadalupe-Grau A, Fuentes T, Guerra B, Calbet JA. Exercise and bone mass in adults. Sports Med. 2009;39(6):439-68.

51. Gómez-Bruton A, Gónzalez-Agüero A, Gómez-Cabello A, Casajús JA, Vicente-Rodríguez $\mathrm{G}$. Is bone tissue really affected by swimming? A systematic review. PLoS One. 2013;8(8):e70119.

52. Kohrt WM, Bloomfield SA, Little KD, Nelson ME, Yingling VR; American College of Sports Medicine. American College of Sports Medicine Position Stand: physical activity and bone health. Med Sci Sports Exerc. 2004;36(11):1985-96.

53. Ruoti RG, Toup JT, Berger RA. The effects of nonswimming water exercise on olders adults. J Orthop Sports Phys Ther. 1994;19(3):140-5.

54. Moreira LD, Fronza FC, Dos Santos RN, Zach PL, Kunii IS, Hayashi LF, et al. The benefits of a high-intensity aquatic exercise program (HydrOS) for bone metabolism and bone mass of postmenopausal women. J Bone Miner Metab. 2013; Sep 19. [Epub ahead of print].

55. Nachemson AMD. The load on lumbar disks in different positions of the body. Clin Orthop Relat Res. 1966;45:107-12.

56. Sinaki M, Mikkelsen BA. Postmenopausal spinal osteoporosis: flexion versus extension exercises. Arch Phys Med Rehabil. 1984;65(10):593-6.

57. Buehring B, Viswanathan R, Binkley N, Busse W. Glucocorticoid-induced osteoporosis: an update on effects and management. J Allergy Clin Immunol. 2013;132(5):1019-30.

58. van Staa TP, Geusens P, Zhang B, Leufkens HG, Boonen A, Cooper C. Individual fracture risk and the cost-effectiveness of bisphosphonates in patients using oral glucocorticoids. Rheumatology (Oxford). 2007;46(3):460-6.

59. Taylor BC, Schreiner PJ, Stone KL, Fink HA, Cummings SR, Nevitt MC, et al. Long-term prediction of incident hip fracture risk in elderly white women: study of osteoporotic fractures. J. Am Geriatr Soc. 2004;52(9):1479-86. 